\title{
EU GAAP first!
}

\author{
Ralph ter Hoeven
}

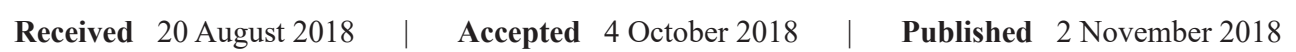

Nationalistische sentimenten zijn goed waarneembaar tijdens verkiezingen in het algemeen en referenda in het bijzonder. Denk aan 2005 toen onverwacht door Nederland 'nee' werd gezegd tegen het Verdrag tot vaststelling van een Europese Grondwet. De tegenstanders van deze Grondwet verzetten zich naar eigen woorden 'tegen een verlies van soevereiniteit aan een ondemocratische en bureaucratische Europese superstaat' (soevereiniteit). Bovendien was de SP gekant tegen wat zij noemde: een grondwettelijke verankering van de Europese interne markt als exponent van een vrijemarkteconomie (marktordening). Toe maar.

Soevereiniteit en marktordening waren de leidmotieven 13 jaar terug. En deze motieven hebben ook ten grondslag gelegen aan de uiteindelijke uitkomsten van de referenda over de Brexit, het associatieverdrag met de Oekraïne en de keuze voor Trump als president van de Verenigde Staten. In dit klimaat is het niet verwonderlijk dat ook als het gaat om de bevoegdheid tot het opstellen van verslaggevingsregels voor (beurs)ondernemingen, dezelfde sentimenten opspelen. Deze verslaggevingsregels, zoals IFRS, worden aangeduid met de term Generally Accepted Accounting Principles (GAAP). Het gaat dus niet om acceptable accounting regels maar om 'accepted' regels. Voordat sprake kan zijn van acceptatie zal een beoordeling en een goedkeuring moeten plaatsvinden. Alleen dan kunnen we immers spreken van een voltooide tijd (accepted).

In de Europese Unie komen al deze elementen samen in het zogenoemde endorsement process van nieuwe IFRS-standaarden. Zowel technische expert-organen als politieke organen moeten goedkeuring verlenen als een nieuwe standaard het licht ziet. Zo zijn nog niet zo lang geleden de belangrijke standaarden IFRS 9 (financiële instrumenten), IFRS 15 (omzetverantwoording) en IFRS 16 (leases) goedgekeurd door de Europese Unie. Alsdan worden deze standaarden vertaald in alle offici- ele talen van de EU en opgenomen in het Europees $\mathrm{Pu}$ blicatieblad. En daarmee als Europese wet erkend. Een wet die inmiddels honderden pagina's aan (vertaalde) IFRS-standaarden bevat. Je zou dit met enige fantasie een GAAP-immigratie kunnen noemen. De GAAP wordt immers opgesteld door een niet-EU orgaan (IASB). En de meerderheid van IASB bestaat uit leden die afkomstig zijn uit landen buiten de EU.

Gezien het eerder beschreven sentiment is het niet verwonderlijk dat ook bij deze 'immigratie' vragen worden gesteld door het 'gastland' in kwestie, in dit geval de EU. Deze vragen zijn door de Europese Commissie in letterlijke zin gesteld in een EU-consultatiedocument genaamd Fitness Check on the EU Framework for Public Reporting by Companies. Een document dat maar liefst 66 vragen bevat over een variëteit aan onderwerpen. De rode draad is: hebben we in Europa nog wel een goed raamwerk van verslaggevingseisen (GAAP) voor de verschillende soorten ondernemingen die aan onderdelen van dit raamwerk moeten voldoen? En is dit raamwerk nog wel geschikt (fit) voor de toekomst? Ronduit interessant zijn de 12 vragen over de immigrant (IFRS) in kwestie. In de inleiding op de Fitness Check komen we in dit kader de volgende passage tegen:

The current endorsement process prevents the Union from modifying the content of the standards issued by the $I A S B$. Some stakeholders, as mentioned in the final report of the High-Level Expert Group (HLEG) ${ }^{1}$, are concerned that this lack of flexibility would prevent the EU from reacting if these standards were to pose an obstacle to broader EU policy goals such as long-term investments and sustainability.

Een op zijn minst selectieve waarneming die veel lijkt te zeggen over hoe de EC nu tegen IFRS aankijkt en ongelukkig is als het doel is om in een consultatiedocument 
onbevooroordeelde visies van stakeholders boven water te krijgen. Let bijvoorbeeld eens op vraag 20:

Since the adoption of IFRS by the EU in 2005, topics such as sustainability and long-term investment have come to the forefront of the regulatory agenda. Is the EU endorsement process appropriate to ensure that IFRS do not pose an obstacle to broader EU policy objectives such as sustainability and long-term investments?

- Yes

$-\quad N o$

- Don't know

If you answered "No", please explain your position.

Een opmerkelijke vraag die begint met een niet gestaafde bewering die overigens aansluit op de genoemde inleidende tekst waarin de Europese Commissie een expertgroep aanhaalt die zich duidelijk in het 'nee-kamp' bevindt. Degenen die nu nog 'yes' durven aan te kruisen worden verder niet meer naar hun motivering gevraagd. In tegenstelling tot degenen die een nee-stem uitbrengen. Als een van mijn scriptiestudenten een dergelijke enquête aan mij ter beoordeling zou voorleggen, zou ik de goede man of vrouw er toch echt niet mee weg laten komen.

Het negatieve sentiment ligt mijns inziens in het beginsel van voorzichtigheid dat prominent voorkomt in de Europese jaarrekeningrichtlijn (en wetshistorie) maar veel minder in IFRS. Een aantal jaar geleden waagde de IASB het zelfs om het voorzichtigheidsbeginsel te schrappen uit het Conceptual Framework, tot grote ontsteltenis van met name het Europees Parlement (dat zelfs de financiering van de IASB aan banden dreigde te leggen als dit orgaan het principe van prudence niet in ere zou herstellen). En de grootste veroorzaker van imprudence binnen IFRS is de waarderingsgrondslag fair value. De figuurlijke rode lap in het GAAP (immigratie)debat. Het is immers deze fair value grondslag die ongerealiseerde winsten al meeneemt in de prestatiemaatstaven en die volgens 'sommige stakeholders' eraan bijdraagt dat organisaties niet meer duurzaam in aandelen willen beleggen. Immers, volgens deze stakeholders: als je een lange termijn horizon voor ogen hebt, waarom zou je dan veranderingen in marktwaarde willen bijhouden? Weg dus met die volatiliteit die deze GAAP-indringer fair value veroorzaakt.

Uiteraard, tegen deze redenaties valt veel, heel veel, in te brengen. Ik wijs alleen maar op mijn in 2006 uitgesproken oratie over de zin en onzin van fair value (Ter Hoeven 2006). Maar is dat niet bij elke redenatie gebaseerd op sentiment het geval? Denk wederom aan de genoemde referenda en de op zijn zachtst gezegd ongenuanceerde beweringen van het nee-kamp. U weet nog wel: 'EU-geld kan voortaan naar de Britse ziekenhuizen.'

Ik voorzie dus moeilijke tijden als het gaat om de acceptatie van IFRS-standaarden in de toekomst. De EU lijkt voor te sorteren op het plaatsen van grenscontroles en het invoeren van bevoegdheden om ongewenste elementen in de standaarden te weren. Kortom, vrij naar de op dit moment machtigste man van de westerse wereld: EU GAAP first.

- Prof. dr. R.L. ter Hoeven RA is partner op het vaktechnisch centrum van Deloitte Accountants en is als hoogleraar Externe Verslaggeving verbonden aan de Rijksuniversiteit Groningen.

\section{Noten}

1. European Commission (2018): https://ec.europa.eu/info/publications/180131-sustainable-finance-report_en

\section{Literatuur}

- European Commission (2018) Financing a sustainable European Economy. Final report of the High-Level Expert Group on Sustainable Finance. https://ec.europa.eu/info/publications/180131-sustainable-finance-report_en
- Ter Hoeven RL (2006) De waarderingsgrondslag 'fair value' in de jaarrekening; een aanzet tot conceptuele inkadering. Maandblad voor Accountancy en Bedrijfseconomie 80(12): 620-628. 